(A Peer-Reviewed, Open Access Journal)

\title{
Satisfaction and Utilization of Old Age Allowance among Dalit Community in Pokhara, Nepal
}

\author{
Ananta Raj Dhungana, PhD* \\ Mala Ranabhat**
}

DOI: https://doi.org/10.3126/jnbs.v13i1.34724

\section{ABSTRACT}

This study aims to explore the satisfaction and utilization of old age allowance among the Dalit Community in Pokhara, Nepal. For this purpose, Pokhara was purposively selected at first. Out of 553 Dalit respondents from randomly selected wards (13, 16, 26 and 29) of Pokhara Metropolitan City of Nepal who were getting old age allowance, information was collected purposively from 131 respondents using structured questionnaire through interview techniques. Hence, a multistage sampling technique was applied during the sample collection. Both descriptive as well as exploratory research design was used for the study. The majority of elderly Dalit are illiterate, unemployed and living jointly with their family. For most of the respondents, allowance is the major source of personal income. Most of them spend allowance for their own expenses. The majority of respondents are satisfied with the present allowance but still, there is the demand for increasing the allowances as it is so insufficient for their basic needs. On the basis of priority, most of the respondents spend their money on food for household consumption, health and medicines, transportation expenses, alms, clothes for self and tobacco, alcohol accordingly. Most of them have not faced difficulties in getting allowances. However, some of them have faced difficulties to travel to authorized office or bank to collect allowance due to their age, are not receiving allowance timely, late receiving allowance due to age error in documents, do not get paid the full amount and they feel a lot of administrative hassles. Hence the government should give attention to the problem faced by the respondents while receiving the old age allowance.

Keywords: Dalit community, old age allowance, satisfaction, unemployed, utilization

\footnotetext{
*Dr. Dhungana is an Assistant Professor at the School of Development and Social Engineering, Pokhara University.

${ }^{* *}$ Ms. Ranabhat is a Graduate student from School of Development and Social Engineering, Pokhara University.

Corresponding Author: Dr. Ananta Raj Dhungana, Email: anantastat@gmail.com
} 


\section{INTRODUCTION}

Social exclusion in Nepal reflects the hierarchies of the Hindu caste system that divides the population into 'upper' and 'lower' caste people (World Bank, 2006). Despite representing about 13.1 percent of the Nepalese population (CBS, 2011), Dalits have failed to unite and clearly articulate their political agenda. Dalits continue to remain one of the most economically marginalised, politically excluded and socio-culturally oppressed communities in Nepal (Dahal, Gurung, Acharya, Hemchuri, \& Swarnalkar, 2002; Kabeer, 2006; UNDP, 2008; Sunar, 2008). Published statistics indicate that Dalits as a group are significantly below the national average in most development indicators such as poverty $-48 \%$; literacy $-40 \%$; chronic childhood malnutrition - 60\%; food deficiency- $85 \%$; and life expectancy-48 years (CBS, 2011).

The National Dalit Commission of Nepal (NDC-Nepal) has identified about 26 castes of which 7 are Hill Dalits (of which two belonged to the Newar community) and the remaining 19 Madhesi Dalits (NDC, 2014). Whilst all Dalit castes have suffered various forms of caste-based discrimination, the problems associated with these communities are not the same. This is partly because of different geographic locations, cultural practices, rites and rituals, and languages. Although untouchability has been the common suffering of all Dalits, their experience of social exclusion was varied, with Dalits in the Terai on the southern plains bordering India, getting more disadvantages than Dalits in the Hills. The problems encountered by Terai Dalits included landlessness, lack of citizenship, illiteracy, poverty, child marriage, dowry system and the social boycott by non-Dalits (NDC, 2014).

Ageing is a continuous, universal, progressive, intrinsic, and deleterious process. There is a lack of separate effective schemes for elderly peoples' health care facilities in Nepal (Yadav, 2012). The conference paper of Uprety (2006) shows that provisions for the protection and advancement of the senior citizen, however, fall far short of rapidly growing needs.

Increasingly, social security is being considered as a right of the citizen. Social security is linked to enhancing social equity and justice. Together with the global movement and according to the commitment expressed in the international forums government of Nepal has initiated to respond to the social security need of the people and started some programmes at the national level. First, the social security allowance was introduced by former Prime Minister Manmohan Adhikari as an old age allowance on December 26, 1994; originally started as a monthly cash transfer of 100 Nepalese rupees to citizens of 75 years and above. Five districts from the five development regions of Nepal were selected to pilot the scheme, and the first disbursement of the old age allowance program (OAP) was made on July 2, 1995 , for a six-month period from January to June. The implementation of the pilot project in five districts was carried out by the Ministry of Education and Sports and distributed at the 
grass-roots level by the village development committees. During the fiscal year, 1995-96, the OAP was extended to the entire country and was implemented by the Home Ministry. During 1995-96, Rs. 280 crores were released for the implementation of the program. Since 1996-97, the Ministry of Local Development has been administrating the OAP, and the allowances were distributed by the ward offices in the urban areas and VDCs in the rural areas. When the Nepali Congress came to power through a verdict of the electorate in 1996-97, it introduced two additional social security programs, namely the helpless widow's allowance for widows above 60 years of age and the disabled pension of Rs. 100 per month. In the International Year of Elderly Persons (1999), the ruling Nepali Congress raised the old age allowance from Rs. 100 to 150. All Nepalese, men and women, who had completed 75 years of age and above were eligible for the pension. According to the directives issued by the Ministry of Local Development, the age mentioned in the Nepalese citizenship certificate is the basis for accessing the old age allowance. In 1996, the widow's allowance and disability pension were introduced.

Since 2008/09, the government has been introducing allowances to single women, endangered races, while reducing the eligibility age threshold for Dalits and citizens of the Karnali zone (National Planning Commission, 2012). Since September 2009 onwards, the Maoist government added a new scheme called a child protection grant or child grant which would provide Dalit children and children in Karnali under the age of five a monthly allowance of NRs.200. The Maoist government also expanded the category of widow allowance to include all single women over 60 , i.e., those who were widows, never married and legally separated from their husbands. In March 2010, the Supreme Court ruled that widows of any age should be eligible for the benefit and this further expanded the coverage of widow allowance. In FY 2014-2015 AD, the quota for partially disabled applicants has been removed.

Joshi (2012) conducted a study to investigate the effectiveness of senior citizen social security allowance scheme in Dhangadhi Municipality. The study found that male respondents have more knowledge about social security allowances than female respondents. Senior citizens utilized allowances for self expenditure and household expenditure. Similarly, the study found that senior citizen allowance has improved their status in the family but the elderly allowance is inadequate to meet their overall basic necessities.

With the growing rise in the budgetary allocation over the years to this program, there is a growing concern regarding the effectiveness of the program. The present study was carried out to explore the utilization and effectiveness of old age allowance and problems faced by Dalit people living in Pokhara, Nepal. This study is also believed to be fruitful for the agencies of the government of Nepal to assess the effectiveness of the program and improve the distribution system more effectively and efficiently. Further, the study will also help plan future policies and programs to improve the status of Dalit people. 


\section{DATA AND METHODS}

At first, Pokhara Metropolitan City was selected purposively. In the second stage, out of 33 wards of Pokhara Metropolitan City, four wards i. e. 13, 16, 26 and 29 were selected randomly. In the final stage, out of 553 population, 131 samples (at $7.5 \%$ margin of error and $5 \%$ level of significance) have been proportionately selected from four wards as 58, 36, 13 and 24 respectively (Table 1).

Table 1

Sample Size Distribution

\begin{tabular}{llll}
\hline Ward no. & $\begin{array}{l}\text { Senior citizen Dalit } \\
\text { (Population) }\end{array}$ & Population \% & Sample size \\
\hline 13 & 246 & 44 & 58 \\
16 & 151 & 27 & 36 \\
26 & 56 & 10 & 13 \\
29 & 100 & 18 & 34 \\
\hline Total & 553 & 100 & 131 \\
\hline
\end{tabular}

Source: Department of Civil Registration and Self Calculation

Then the respondents from each ward were selected purposively (Dalits who were receiving old age allowance) and information was collected by using a structured questionnaire. The questionnaire was finalized by pre-testing it in ward no. 14 of Pokhara Metropolitan City for the reliability of data. Data was collected by the co-author herself in June and July of 2018. Hence, the multistage sampling technique was adopted for sample selection in the study area. Both descriptive as well as exploratory research design were applied for this study.

\section{RESULTS}

Based on the analysis of the information collected from 131 respondents, this study has the following findings:

\section{Socio-economic Characteristics of the Respondents}

The different particulars of the respondents especially sex, marital status, family type, family size, major occupation, living arrangement, educational status, location and monthly income of the family have been presented in this section. 
Table 2

Socio-Demographic and Economic Characteristics of the Respondents

\begin{tabular}{|c|c|c|}
\hline Variables & Number & Percent \\
\hline \multicolumn{3}{|l|}{ Sex } \\
\hline Male & 53 & 40.5 \\
\hline Female & 78 & 59.5 \\
\hline \multicolumn{3}{|l|}{ Marital status } \\
\hline Married & 71 & 54.2 \\
\hline Divorce/Widow & 60 & 45.8 \\
\hline \multicolumn{3}{|l|}{ Family type } \\
\hline Joint & 92 & 70.2 \\
\hline Nuclear & 39 & 29.8 \\
\hline \multicolumn{3}{|l|}{ Family size } \\
\hline Alone & 13 & 9.9 \\
\hline $2-4$ & 52 & 39.7 \\
\hline $5-7$ & 53 & 40.5 \\
\hline 8 and above & 13 & 9.9 \\
\hline \multicolumn{3}{|l|}{ Major occupation } \\
\hline Agriculture & 12 & 9.2 \\
\hline Day Labor & 9 & 6.9 \\
\hline Housewife & 37 & 28.2 \\
\hline Unemployed & 57 & 43.5 \\
\hline Others & 16 & 12.2 \\
\hline \multicolumn{3}{|l|}{ Living arrangement } \\
\hline Family & 93 & 71 \\
\hline Spouse & 21 & 16 \\
\hline Alone & 12 & 9.2 \\
\hline Daughter/Son-in-law & 5 & 3.8 \\
\hline \multicolumn{3}{|l|}{ Education status } \\
\hline Illiterate & 104 & 79.4 \\
\hline Literate & 27 & 20.6 \\
\hline \multicolumn{3}{|l|}{ Location } \\
\hline Ward no. 13 & 58 & 44.3 \\
\hline Ward no. 16 & 36 & 27.5 \\
\hline Ward no. 26 & 13 & 9.9 \\
\hline Ward no. 29 & 24 & 18.3 \\
\hline \multicolumn{3}{|c|}{ Monthly income of the family } \\
\hline up to 5000 rupees & 39 & 29.8 \\
\hline 5001 to 10000 rupees & 26 & 19.8 \\
\hline 10001 to 20000 rupees & 22 & 16.8 \\
\hline 20001 to 30000 rupees & 24 & 18.3 \\
\hline Rupees 30001 and above & 20 & 15.3 \\
\hline \multicolumn{3}{|l|}{ Support for basic needs } \\
\hline Self & 57 & 43.5 \\
\hline Family member & 69 & 52.7 \\
\hline Daughter/Son-in-law & 4 & 3.1 \\
\hline Others & 1 & .8 \\
\hline
\end{tabular}

Source: Field survey, 2018 
Table 2 reveals that almost three-fifths of respondents are female and two-fifth of respondents are male. It shows that there is a majority of the females who are getting senior citizen allowance. More than half $(54.2 \%)$ of the respondents are married followed by divorced/widows (45.8\%). A majority (70.2\%) of the respondents are from a joint family and only 29.8 percent are from a nuclear family. Family size here refers to the total no. of family members of respondents who are currently living together. In this study, family size is found from 1 to 18 . Further, most of the respondents $(40.5 \%)$ are found to be living in a family with size 5 to 7 members, followed by 2 to 4 members (39.7\%), 8 and more members $(9.9 \%)$ and 9.9 percent are living alone.

The higher percentage $(43.5 \%)$ of respondents belongs to the unemployed group, more than one fourth $(28.2 \%)$ are housewife, 9.2 percent belongs to agriculture, 6.9 percent belongs to day labor and remaining 12.2 percent belongs to other occupation such as tailor, goldsmith and retail shopkeeper. So, the majority of the respondents who are getting old age allowance are unemployed. More than two-thirds (71\%) of the respondents are found to be living with their family followed by their own spouse (16\%), live alone $(9.2 \%)$, and live with their daughter/son-in-law (3.8\%). The data shows that more than three fourth $(79.4 \%)$ of the respondents are illiterate whereas literate respondents cover only 20.6 percentage.

The monthly income of a family refers to the total income of all the family members of respondents who are living together. Different families have different monthly incomes which range from Rs. 1,000 to Rs. 100,000. The average income of the family per month is Rs. 18,681. More than one-fourth (29.8\%) of the respondents' families have a monthly income of up to 5000 rupees. Further 19.8 percent have the family's monthly income of 5001 to 10000 rupees followed by 20001 to 30000 rupees (18.3\%), 10001 to 20000 rupees $(16.8 \%)$ and 15.3 percent respondents are from the family with a monthly income of rupees 30,000 and above. More than half of the respondents (52.7\%) are supported by the family members for the fulfillment of their basic needs self-supported (43.5\%), their daughter and son-in-law (3.1\%) and only 0.8 percent of respondents are being supported by others for their basic needs.

\section{Utilization of Allowance}

This section includes the basic information related to the area of utilization of allowance. It includes a time of receiving the allowance, allowance as a major source of income or not, spending of allowance and items on which allowance is spent on.

\section{Time of Receiving the Allowance}

Dalit people get old age allowance when they become 60 years old, so from when the beneficiaries are receiving allowance generally depends upon their age. In this study, the time of receiving allowance is divided into six categories (such as 1 to 2 years, 3 to 4 years, 5 to 6 years, 7 to 8 years, 9 to 10 years and above 10 years) which are shown as follows. 


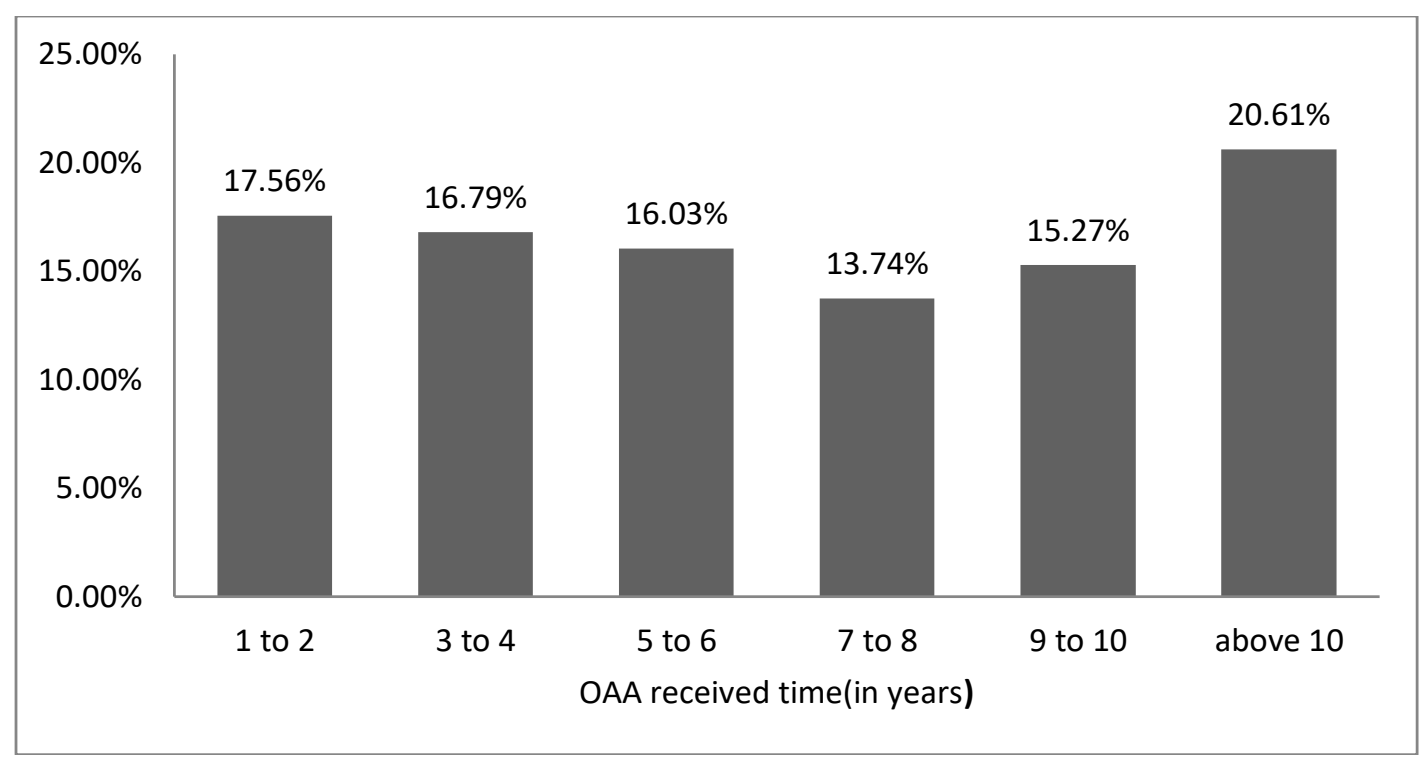

Figure 1. Time of allowance received by respondents.

Figure 1 reveals that the time that the beneficiaries are receiving OAA. Most of the respondents are receiving allowances for more than 10 years (i.e. $20.61 \%$ ), followed by 1 to 2 years $(17.56 \%), 3$ to 4 years $(16.79 \%), 5$ to 6 years $(16.03 \%), 9$ to 10 years $(15.27 \%)$ and 7 to 8 years $(13.74 \%)$ (Figure 1$)$.

\section{Uses of Allowance}

The beneficiaries of the allowance can spend their allowance for anyone. Generally, they spend their allowance on their own expenses or for family members or for both. The following chart shows to which the respondents spend their allowance.

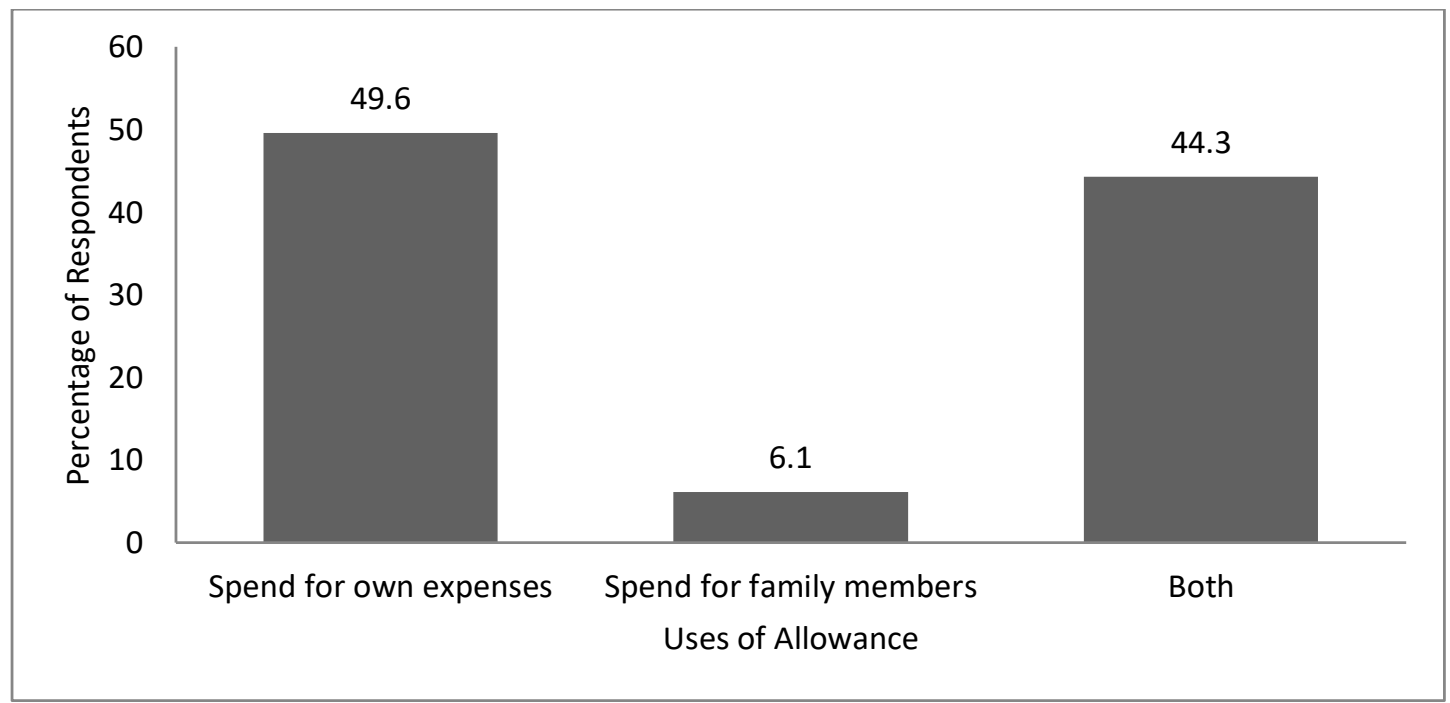

Figure 2. Uses of allowance by respondents. 
Figure 2 shows that almost half (49.6\%)of the respondents spend the allowance for their own expenses. Further, 44.3 percent of respondents spend their allowance on both themselves and their family members. Only 6.1 percent of respondents spend their allowance on family members.

\section{Allowance as a Major Source of Personal Income}

When people become older and older they become inactive and cannot do earning activities. In such a situation they may not have other sources of income. Figure 3 shows whether the allowance is their major income or not.

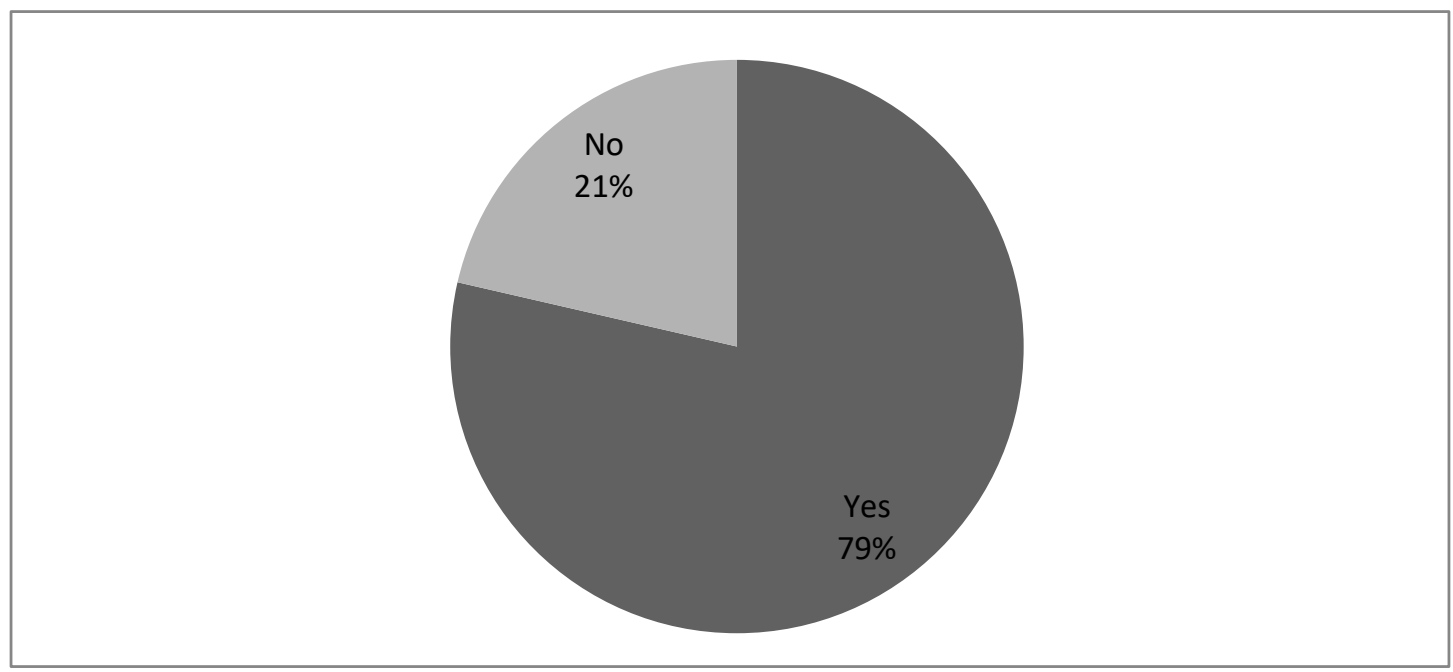

Figure 3. Allowance as major source of income.

More than two-thirds (79\%) of the respondents responded the allowance as the major source of their income and only $21 \%$ of respondents responded that they do not take the allowance as a major source of income.

\section{Items on Which Allowance is Spent on}

The beneficiaries of the allowance can spend their allowance on any items. Generally, they spend their allowance on food, clothes, medicine, transportation, alcohol/ tobacco, entertainment, etc. The following chart shows in which items the respondents spend their allowance along with a priority of expenditure.

According to Table3, under the first priority, most respondents spend their money on food for the $\mathrm{HH}$ consumption (45.8\%). Under the second priority, most respondents spend highly on health and medicines $(46.6 \%)$. Under third priority, people mostly spend their allowances on transportation expenses (10.7\%). Under fourth priority, people spend their 
allowances equally on alms and clothes for self i.e. $2.3 \%$ both. Under fifth priority, respondents are found to spend their allowance more on clothes for themselves $(3.1 \%)$.

Table 3

Items on Which Allowance is Spent

\begin{tabular}{|c|c|c|c|c|c|c|c|c|c|c|c|}
\hline \multicolumn{12}{|c|}{ Percentage of respondents spending their allowance on } \\
\hline Priority & 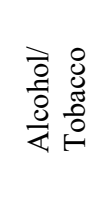 & $\frac{n}{\xi}$ & 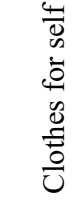 & 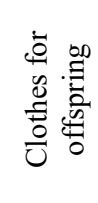 & 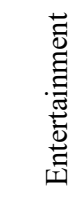 & 苞 & 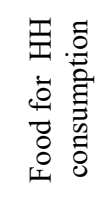 & 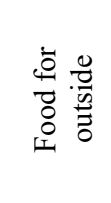 & 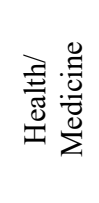 & 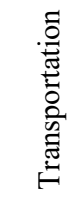 & $\begin{array}{l}\frac{\omega}{\vec{d}} \\
\frac{ \pm}{0}\end{array}$ \\
\hline First priority & 8.4 & 0.8 & 3.1 & 0 & 0 & 2.3 & 45.8 & 3.1 & 20.6 & 1.5 & 1.5 \\
\hline $\begin{array}{l}\text { Second } \\
\text { priority }\end{array}$ & 38.2 & 3.1 & 8.4 & 2.3 & 3.1 & 3.1 & 38.9 & 29.8 & 46.6 & 23.7 & 0 \\
\hline Third priority & 3.1 & 3.8 & 2.3 & 3.8 & 0.8 & 1.5 & 2.3 & 3.1 & 6.1 & 10.7 & 0 \\
\hline $\begin{array}{l}\text { Fourth } \\
\text { priority }\end{array}$ & 0 & 2.3 & 2.3 & 1.5 & 0 & 0.8 & 0 & 0 & & 0 & 0 \\
\hline Fifth priority & 0.8 & 0.8 & 3.1 & 2.3 & 2.3 & 0 & 0 & 0.8 & 1.5 & 1.5 & 0 \\
\hline Not spend & 49.6 & 89.3 & 80.9 & 90.1 & 93.9 & 92.4 & 13 & 63.4 & 25.2 & 62.6 & 98.5 \\
\hline Total & 100 & 100 & 100 & 100 & 100 & 100 & 100 & 100 & 100 & 100 & 100 \\
\hline
\end{tabular}

Source: Field survey, 2018 and authors calculation

\section{Satisfaction with Present Allowance}

An attempt of studying the satisfaction level of the respondents has been made by asking the question of whether the respondents are satisfied with the present allowance or not. It is found that 96 percent of respondents are satisfied with the present allowance as they further said that if the government is providing the allowance free of cost why are not they satisfied with the allowance? Similarly, only four percent of respondents are not satisfied with the present allowance as the amount is very negligible (Figure 4).

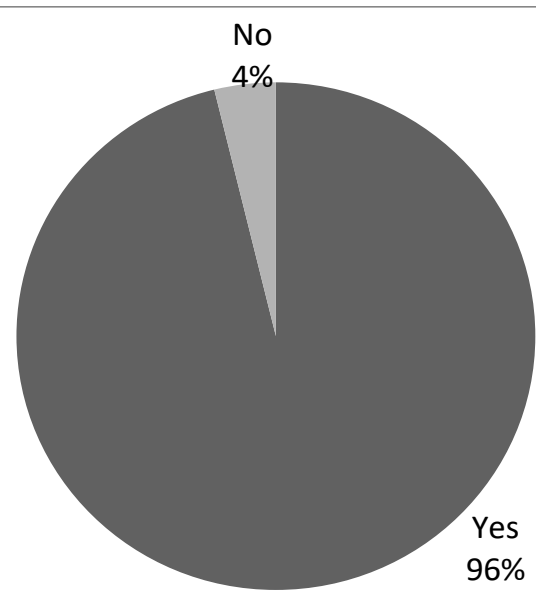

Figure 4. Satisfaction with allowance. 


\section{Perception Towards Old Age Allowance and Expected Amount}

It includes the opinion of the respondents about the necessity of an increase in old age allowance. For this matter, 85 percent of respondents gave positive responses. The major reason for the positive response is the declaration of political leaders during the election campaign, inflation in the economy, costly medical expenses, etc. But only 15 percent of the respondents responded negatively to the same question. The major reason was the increasing financial burden to the government and the working-age population through tax policies (Figure 5).

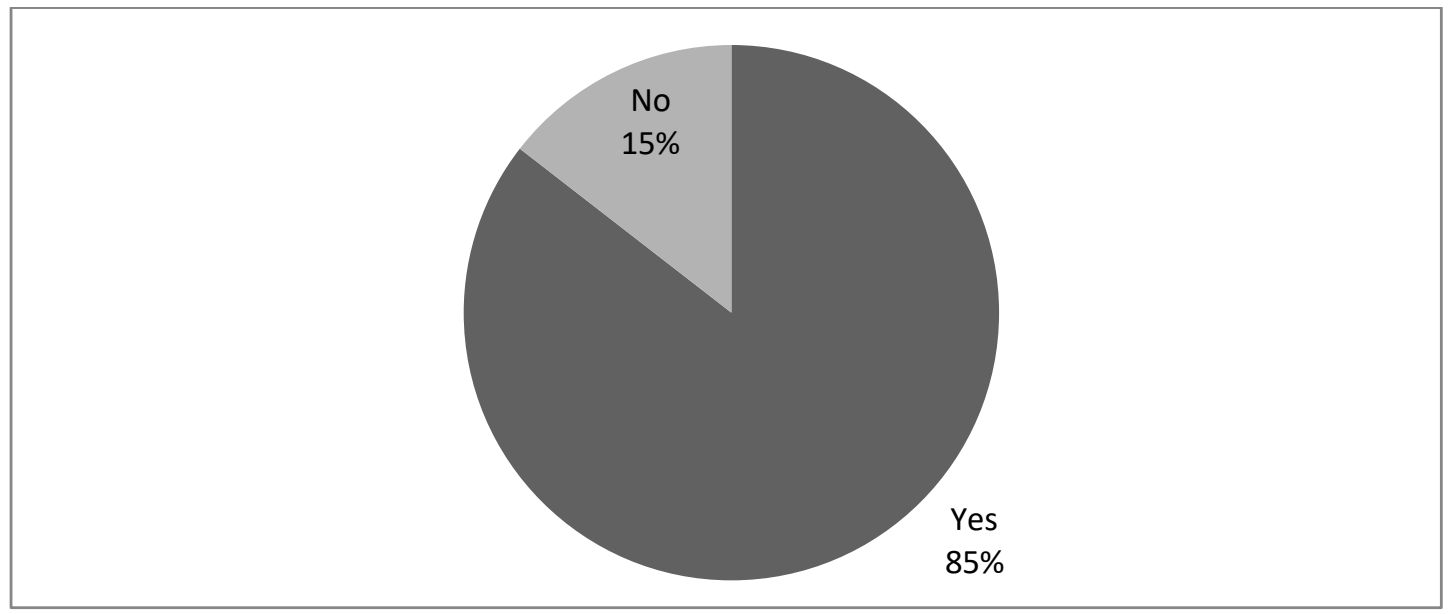

Figure 5. Opinion regarding increment of allowance.

Regarding the expected amount that should be increased, their expectation varied as per their basic needs and their expenses. A huge variation of increment has been found to be expected ranging from Rs. 1000 to Rs. 8000 and above per month which is shown in Figure 6.

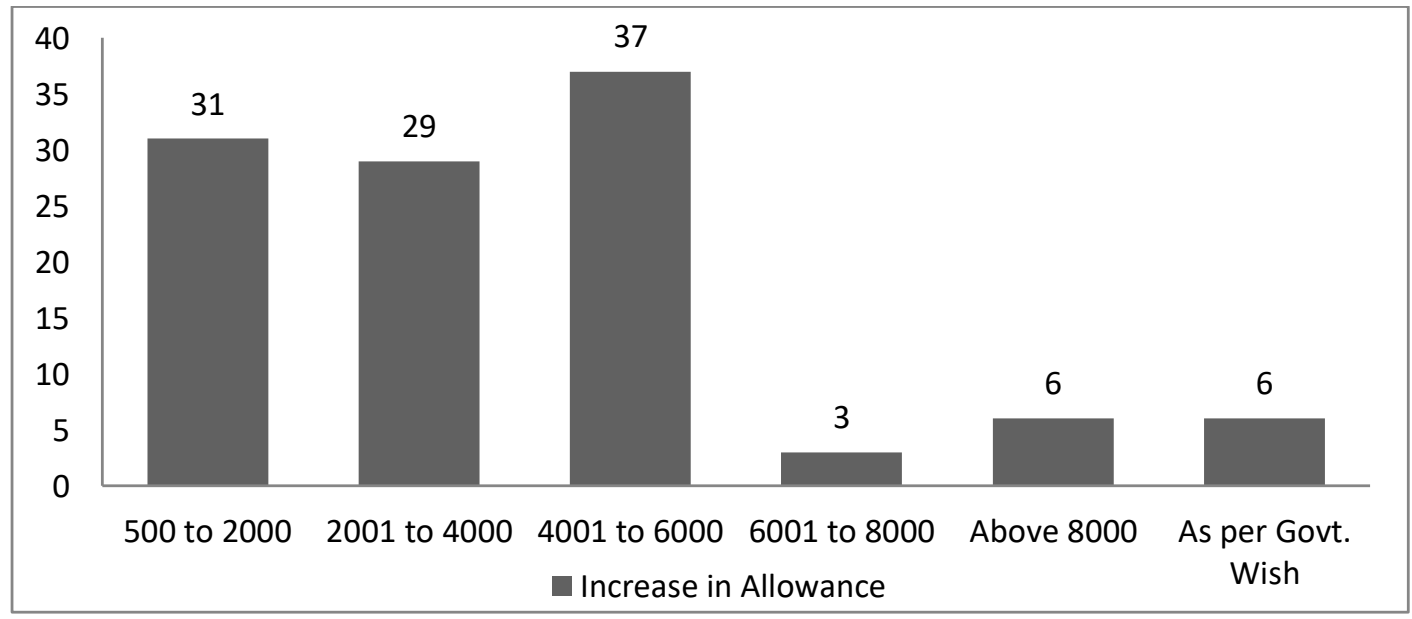

Figure 6. Expected amount that needs to be increased in allowance. 
Out of 85 respondents who have responded that allowance needs to be increased, 31 respondents responded that the increment should be between (500 to 2000) rupees, twentynine respondents responded that the increment should be between(2001 to 4000) rupees, thirty-seven respondents responded that the amount should be increased between (4001 to 6000 ) rupees, and 6 respondents wished the amount of OAA should increase Rs. 8000 and above. Further, six respondents responded the amount of OAA should be increased as per government wish. Only three respondents responded that it should be increased between (6001 to 8000) rupees.

\section{Problems Faced by Respondents While Receiving the Allowance}

More than three-fifths of the respondents responded that they did not face any problem while receiving the allowance but on the contrary, 39 percent of respondents have faced some problems during the reception of their allowance.

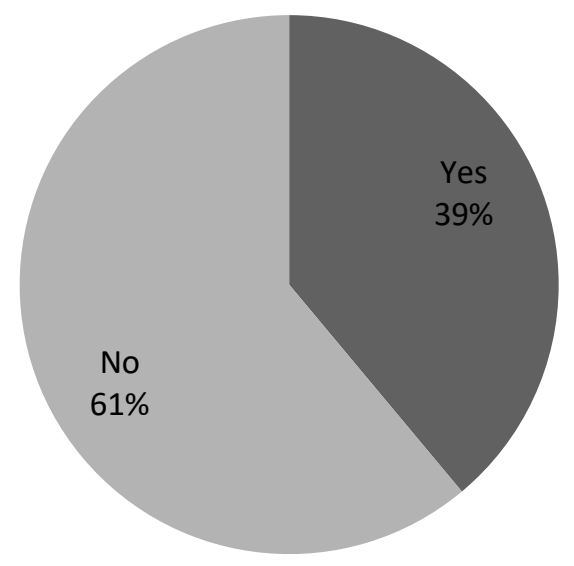

Figure 7. Problem faced while collecting the allowance.

Out of 51 respondents who faced some problems while getting an old allowance, almost one-fifth (18.3\%)of respondents faced difficulties due to their age to travel to VDC or bank to collect the allowance. Almost seventeen percent of respondents mentioned the problem of late receiving of allowances due to age error in the document. More than one in ten respondents faced the problem of untimely distribution of their allowance. Almost five percent of respondents answered that they had to face a lot of administrative hassles during their enrollment; just over three percent of respondents responded that they did not get paid with full allowances. Similarly, just over three percent of respondents said that they were deprived of their allowance due to the delayed reception of their ID cards (Figure 8). 


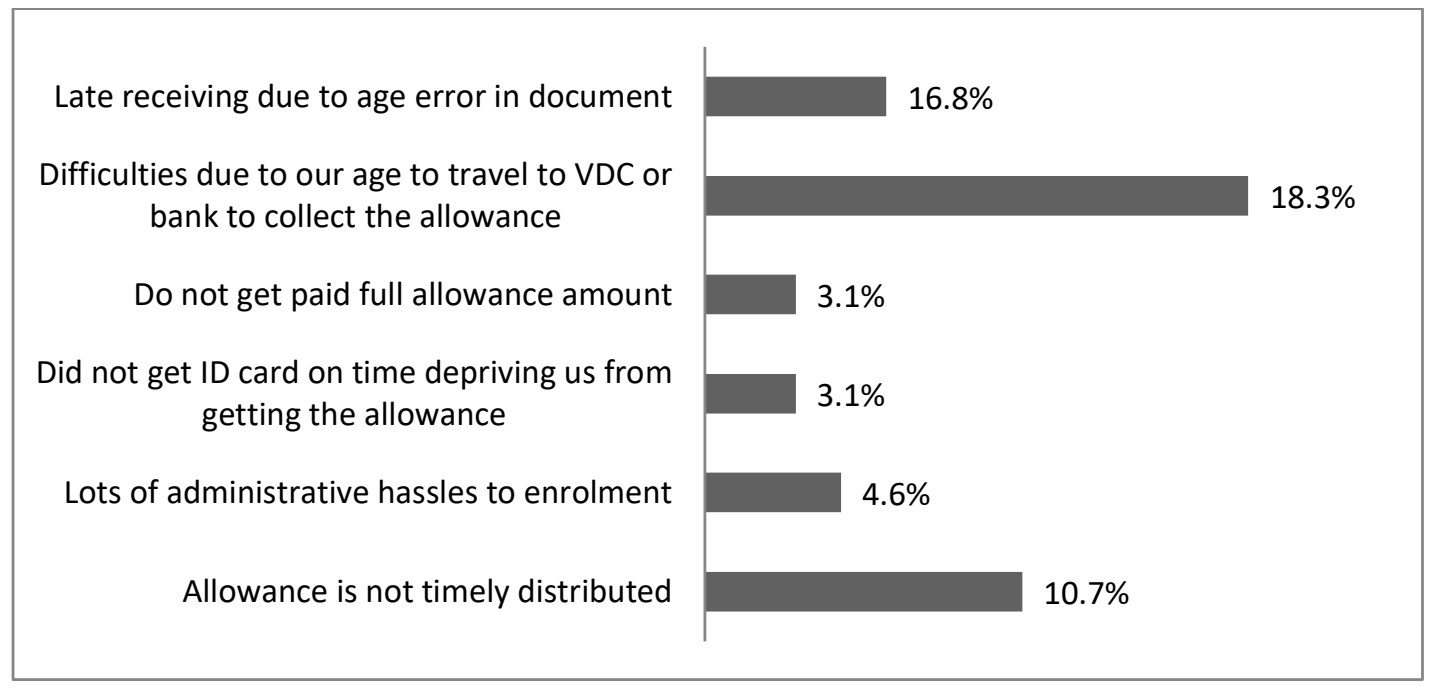

Figure 8. Problems faced by respondents.

\section{CONCLUSION}

Most of the respondents are female, illiterate, unemployed and most of them live with their families. For most of the respondents, allowance is the major source of income. Most of them spend their allowance for their own expenses. The priority wise utilization of old age allowances is towards food for household consumption, health and medicines, transportation, alms, clothes for self and tobacco/alcohol accordingly. The majority of respondents are satisfied with the present allowance but still, there is a demand for increasing the allowances as it is so insufficient for their basic needs. Hence the government should give attention to the problem faced by the respondents while receiving the old age allowance.

\section{Acknowledgement}

The study is based on the data collected for the Master's Degree dissertation of the second author. The dissertation has been submitted to the School of Development and Social Engineering, Faculty of Humanities and Social Sciences, Pokhara University in 2018.

\section{REFERENCES}

CBS. (2011). National Population and Housing Census 2011. Kathmandu: Central Bureau of Statistics.

Dahal, D. R., Gurung, Y., Acharya, B., Hemchuri, K., \& Swarnalkar, D. (2002). National dalit strategies report. Kathmandu: National Planning Commission of Nepal. 
Joshi, M. R. (2012). The effectiveness of senior citizen social security allowance in Dhangadhi Municipality. Working paper. Retrieved from www.academia.edu/download/35256541/KMC_article.docx

Kabeer, N. (2006). Social exclusion and the MDGs: Challenge of durable inequalities in the Asian context. IDS Bull, 37 (3), 64-78.

National Planning Commission. (2012). Assessment of social security allowance program in Nepal. Kathmandu: National Planning Commission. Retrieved from http://www.npc.gov.np/images /category/Assessment-of-Social-Security-AllowanceProgram-in-Nepal.pdf

NDC. (2014). Dalit Caste Index. Kathmandu: National Dalit Commission.

Sunar, N. K. (2008). Socio-economic and political status of Pattharkatta: A case from Kapilvastu District. Social Inclusion Research Fund (SIRF), SNV, Kathmandu.

UNDP. (2008). The Dalits of Nepal and a new constitution. Retrieved fromhttp://idsn.org/uploads /media/DalitsOfNepalAndTheNewConstitution.pdf

Uprety, C. F. (2006). Ageing and social security system in Nepal: Scope and challanges. Network of Asia-Pacific Schools and Institutes of Public Administration and Governance. Sydney: University of Sydney.

World Bank, (2006). Unequal citizens: Gender, caste and ethnic exclusion in Nepal. Washington DC: World Bank. Retrieved from http://documents.worldbank.org /curated/en/ 201971468061735968/Summary

Yadav, R. K. (2012). Aging population in Nepal: Challenges and management. Academic Voices: A Multidisciplinary Journal, 2(1), 48-53. 